\title{
THE IMPACT OF VOCATIONAL TRAINING ON LABOR MARKET OUTCOMES IN THE PHILIPPINES
}

Paul Vandenberg and Jade Laranjo

NO. 621

October 2020
ADB ECONOMICS WORKING PAPER SERIES 


\section{ADB Economics Working Paper Series}

\section{The Impact of Vocational Training on Labor Market Outcomes in the Philippines}

Paul Vandenberg and Jade Laranjo

No. 621 | October 2020
Paul Vandenberg (pvandenberg@adb.org) is a senior economist and Jade Laranjo (jlaranjo@adb.org) is an associate economics analyst at the Economic Research and Regional Cooperation Department of the Asian Development Bank. 
(C) 2020 Asian Development Bank 6 ADB Avenue, Mandaluyong City, 1550 Metro Manila, Philippines

Tel +632 8632 4444; Fax +63286362444

www.adb.org

Some rights reserved. Published in 2020.

ISSN 2313-6537 (print), 2313-6545 (electronic)

Publication Stock No. WPS200274-2

DOI: http://dx.doi.org/10.22617/WPS200274-2

The views expressed in this publication are those of the authors and do not necessarily reflect the views and policies of the Asian Development Bank (ADB) or its Board of Governors or the governments they represent.

ADB does not guarantee the accuracy of the data included in this publication and accepts no responsibility for any consequence of their use. The mention of specific companies or products of manufacturers does not imply that they are endorsed or recommended by ADB in preference to others of a similar nature that are not mentioned.

By making any designation of or reference to a particular territory or geographic area, or by using the term "country" in this document, $A D B$ does not intend to make any judgments as to the legal or other status of any territory or area.

This work is available under the Creative Commons Attribution 3.0 IGO license (CC BY 3.0 IGO)

https://creativecommons.org/licenses/by/3.0/igo/. By using the content of this publication, you agree to be bound by the terms of this license. For attribution, translations, adaptations, and permissions, please read the provisions and terms of use at https://www.adb.org/terms-use\#openaccess.

This CC license does not apply to non-ADB copyright materials in this publication. If the material is attributed to another source, please contact the copyright owner or publisher of that source for permission to reproduce it. $\mathrm{ADB}$ cannot be held liable for any claims that arise as a result of your use of the material.

Please contact pubsmarketing@adb.org if you have questions or comments with respect to content, or if you wish to obtain copyright permission for your intended use that does not fall within these terms, or for permission to use the ADB logo.

Corrigenda to ADB publications may be found at http://www.adb.org/publications/corrigenda.

Note:

ADB recognizes "Korea" as the Republic of Korea.

The ADB Economics Working Paper Series presents data, information, and/or findings from ongoing research and studies to encourage exchange of ideas and to elicit comment and feedback about development issues in Asia and the Pacific. Since papers in this series are intended for quick and easy dissemination, the content may or may not be fully edited and may later be modified for final publication. 


\section{CONTENTS}

TABLES iv

$\begin{array}{lll}\text { ABSTRACT } & \mathbf{v}\end{array}$

$\begin{array}{lll}\text { I. INTRODUCTION } & 1\end{array}$

$\begin{array}{ll}\text { II. } & \text { EXISTING THEORY AND EVIDENCE }\end{array}$

III. TECHNICAL AND VOCATIONAL EDUCATION AND TRAINING 4 IN THE PHILIPPINES

IV. MODELS AND METHODOLOGIES

$\begin{array}{lll}\text { V. } & \text { CHARACTERISTICS OF THE SAMPLE } & 7\end{array}$

$\begin{array}{ll}\text { VI. RESULTS } & 10\end{array}$

$\begin{array}{ll}\text { VII. CONCLUSION } & 15\end{array}$

$\begin{array}{ll}\text { REFERENCES } & 17\end{array}$ 


\section{TABLES}

1 Summary Statistics of Selected Profile by Highest Education Level 8

2 Characteristics of Workers Who Completed Secondary School and Post-Secondary 9

Technical and Vocational Education and Training

3 Share of Persons Employed in the Sample 10

4 Determinants of Wage 11

$5 \quad$ Number of Post-Secondary Technical and Vocational Education and Training 12 by Highest Year Completed

6 Logistic Regression for the Propensity Score (Technical and Vocational Education 13 and Training versus Other Levels of Education)

7 Differences in Log Monthly Wage between Technical and Vocational Education and Training and Other Levels of Education Using Propensity Score Matching

8 Employment Probability, Marginal Effects 


\begin{abstract}
The paper analyzes the labor market outcomes of graduates of post-secondary technical and vocational education and training (TVET) in the Philippines. Based on human capital theory, our guiding assumption is that investment in education is rewarded through higher wages and a greater likelihood of being employed. Using household data for 2015-2016, the results show significantly higher wages for TVET graduates relative to those who entered the job market with a secondary school education or below. However, individuals who both trained in TVET and pursued tertiary (university) education tend to have a lower wage than those with secondary school education or below. This counterintuitive result is explained by the tendency for such dual-level individuals to complete the lowest level of TVET. Another result is that TVET graduates are more likely to be employed than both those who only studied at secondary school or below and those who studied at the tertiary level. The results are generated from a linear regression model that corrects for sample selection into employment and from the use of propensity score matching which addresses selection into TVET.
\end{abstract}

Keywords: labor market, Philippines, skills training, TVET

JEL codes: $126, \mathrm{~J} 24$ 


\section{INTRODUCTION}

Education allows people to secure employment and pursue an occupation. It provides an "in" to the labor market and an opportunity to earn a decent wage or salary. This may not be the sole reason for education as it also provides personal development and the opportunity to pursue an interest. Nonetheless, for most people, employment is a key reason they expend time, effort, and money, particularly on post-compulsory education at college or university.

It is possible, however, that education does not result in the intended labor market outcome. On the demand side, an individual may pursue an area of study for which employers are not hiring. The job seeker falls victim to what is known as a horizontal skills gap. On the supply side, the poor quality of education, in terms of curriculum, facilities, or teaching, may result in very little learning taking place. Employers may perceive that graduates have limited knowledge and few skills, and their diploma or degree is of little value. This is part of the vertical skills gap. An employer may see little difference in hiring a graduate in a specialized field from someone with basic education, as both need further training by the employer. While the above scenarios would seem to go against the logic of educationfor-employment, the possibility of weak labor market outcomes is very real. ${ }^{1}$

Governments and development partners have sought to increase enrollment, particularly in primary and secondary education, under the banner of "education for all" and an effort to achieve the Millennium Development Goal of universal access to primary education. As a result of these efforts, enrollment, which is considered a quantity measure, has risen considerably in most parts of the developing world. The focus has now shifted to the quality of education under a new concern that there is a "learning crisis" in which children are in the classroom but not learning very much. The availability of international test results, particularly for 15-year-olds under the Programme for International Student Assessment (PISA), has provided the evidence underlying the learning crisis.

The lack of similar test results makes it more difficult to verify a learning crisis at the postsecondary level. However, as this level of education prepares students more directly for the labor market, labor market outcomes may be a more appropriate indicator of the quality of education. ${ }^{2}$ In effect, employers become the judge. This quality check may be particularly relevant for technical and vocational education and training (TVET) as it has an equal and possibly more direct intent to educate for the labor market than the university system. In developed countries, TVET is generally effective in securing employment because of both the quality of instruction and the focus on skills needed in the workplace. In developing countries, the quality of TVET may suffer from the same deficiencies that have caused a learning crisis in primary and secondary education.

This paper examines the labor market outcomes of post-secondary TVET in the Philippines. The outcome is defined as both the level of wages or salary (wage effect) and ability to secure a job (employment effect). The research can make an important contribution to the question of whether significant reform is needed to the TVET system. Very weak labor market outcomes might suggest a need for major reforms, whereas decent outcomes would indicate that modest improvements may be sufficient. The succeeding sections of the paper are structured as follows. The second section reviews

1 This study focuses on the supply side, but certainly the demand by employers for people with education and skills will be a determinant of whether trained graduates secure employment and are offered good wages.

2 However, if the market is inefficient at matching skills supply with demand, then good quality graduates may not find good paying jobs that utilize their skills. 
some of the literature on the topic, notably the empirical work. The third section outlines the Philippine education system with an emphasis on TVET. The fourth section presents the model and empirical methods used, and the fifth provides the education and labor force characteristics of the sample. The sixth section presents and discusses results. A final section concludes.

\section{EXISTING THEORY AND EVIDENCE}

The concept of human capital was developed more than half a century ago by Schultz (1961), Becker (1964), and Mincer (1974) and remains a powerful conceptual framework to understand the link between education and work. Human capital is the aggregate of knowledge, skills, abilities, and aptitudes that an individual possesses and can be used to contribute to productive work. Greater human capital contributes to increased and better output, in terms of efficiency and the quality of work, and thus can command a higher wage. Individuals can accumulate human capital through education, training, and experience. Because human capital can be costly to accumulate, there is a relationship between the spending (i.e., investment) in education and the return through the wages paid to a worker in employment. In this way, knowledge is viewed as "capital" just like physical capital (plant and machinery) or financial capital, and thus links investment and return.

TVET can be categorized into four main types according to its location within the education and employment system: (i) secondary (high) school vocational education; (ii) post-secondary technical and vocational education; (iii) short-course training as part of active labor market policies (ALMP) targeting youth and the unemployed; and, (iv) employer-sponsored training, also known as inservice or on-the-job training. ${ }^{3}$ The length and intensity can differ across types and, for assessing the impact, the control group of untrained individuals can be different. For example, students who complete secondary TVET are compared against their peers in the secondary school academic stream, whereas post-secondary TVET graduates are compared against secondary school graduates who do not proceed to further education. Creating an appropriate control group is one of the key methodological challenges in assessing impact of TVET and has prompted the use of experimental designs and randomized control trials, where possible (ADB 2015). Impact is normally assessed in terms of two labor market outcomes, notably the wage effect and the employment effect. The basic idea is that those with TVET receive a higher wage and are more likely to be employed than those (control group) who did not pursue TVET.

Bettinger et al. (2010) assess the differences between those who received funding vouchers for private vocational education from those who did not. Those who received the vouchers, which were allocated by lottery, were more likely to stay in vocational school (and not transfer to academic programs). They were also more likely to complete secondary school and score better on final exams than those who did not receive a voucher. The study did not specifically address whether vocational

3 The four-part categorization is based on the authors' knowledge of the different types of TVET. Studies on the first three methods are cited in the rest of the section. Evaluation of the fourth type (on-the-job training) is difficult and there are few robust studies. Note that the term 'on-the-job training' can have different meanings. Strictly speaking, it is training done while working, usually supervised by a mentor. Employers may, however, take workers away from their work (the production line, the store front, etc.) and provide training in another part of the facilities or send workers to train with a training provider offsite. 
education is better or worse than pursuing the academic streams but did conclude that a private vocational education may generate better academic results than public academic programs.

Malamud and Pop-Eleches (2010) exploited a natural experiment in Romania in which 2 years of general education were added and vocational education was shortened. The study found no difference in the wage effect and the employment effect between students affected by the change compared to those who attended secondary school prior to the change. Field et al. (2019) estimate the wage and employment differences of those who studied in competitive (oversubscribed) Mongolian secondary TVET programs relative to those who studied in other vocational programs, and some who pursued the academic stream. In a randomized controlled experiment, those admitted to the competitive schools were selected by lottery from a larger set of applicants who met the admission criteria. Students (male and female) admitted to the competitive schools were more likely to gain employment than those not selected. Women from the competitive schools received higher wages than those who were not selected. However, men selected received lower wages, although the result was not significant.

Olfindo (2018) studied the impact of vocational education on wages in the private sector, using labor force survey data from the Philippines for 2015. About $80 \%$ of those who received TVET did so at the post-secondary level. TVET graduates earned higher wages than those who only completed secondary school. However, for students who studied both TVET and at the tertiary level (university), wages were lower than for those who undertook only tertiary studies. The author suggests there may be a "penalty" for adding TVET to university education. Propensity score matching (PSM) generated similar results, although statistical significance was not achieved, and balancing properties were not met under certain specifications. For example, those with TVET earned higher wages than those with only secondary school education, and while the results were statistically significant, a test of balancing properties was not satisfied. The employment effect was not tested. Choi (2016) also assessed the impact of TVET on wages in the Philippines using data from the labor force survey of 2014 and found similar significant effects for TVET graduates relative to those who completed only secondary school. However, the estimates did not control for economic background, parents' education, or other factors that might account for differences in ability.

Lee, Han, and Song (2019) studied the impact of nonformal job-related education (considered vocational education) on wages and employment in the Republic of Korea. Such education was correlated with higher wages and a greater likelihood of employment relative to upper secondary school graduates. The education variable was significant across a range of model specifications.

Several key studies have assessed short-course vocational programs that target unemployed youth. Attanasio, Kugler, and Meghir (2011) and Attanasio et al. (2015) studied a program in Columbia that offered 3 months of classroom training followed by 3 months of on-the-job training. More than a year after completion, women were $7 \%$ more likely to be in paid employment and earned $20 \%$ more than those who were not trained. For men, differences were not statistically significant. Card et al. (2011) used a randomized control trial to test a similar program in the Dominican Republic. About 780 youth from low-income households were given 350 hours of training, followed by an internship at a private business. Subsequent employment earnings were about 10\% higher than those of a control group. However, differences in the employment effect between the two groups were not statistically significant.

Hicks et al. (2016) evaluated the impact of vocational education training vouchers on randomly selected youth in Kenya. $42 \%$ of the individuals did not complete the course, despite being provided with adequate funding. Under various model specifications, the wage and employment 
effects were not significant. McKenzie (2017) reviewed 12 studies of eight countries - two of which were in Asia: Turkey and India-and found positive, although small wage and employment effects for those who were trained. Hirshleifer et al. (2016) studied the impact of vocational training on the unemployed in Turkey. About 30 hours of training were provided per week over a 3-month period. Trainees subsequently earned $5.6 \%$ more than similar youths in a control group and had a $2 \%$ higher rate of employment. The results, however, were not statistically significant. Kluve et al. (2016) reviewed 74 studies of youth programs that included skills as a key component and found that just over a third (37\%) showed a significant positive employment effect. Furthermore, the researchers concluded that "much of the difference in performance [among youth employment programs] seems to be related to design and implementation factors, as well as the characteristics of the country and the beneficiaries" (Kluve et al. 2016).

This short review of empirical studies suggests that TVET generally has positive wage and employment effects. However, many of the results are not statistically significant or the significance is not obtained for both the wage and the employment effect. Short-course and longer-course TVET programs can be very different and should be considered separately.

\section{TECHNICAL AND VOCATIONAL EDUCATION AND TRAINING IN THE PHILIPPINES}

Prior to 2011, the Philippine education system consisted of 6 years of primary (elementary) school followed by 4 years of secondary (high) school, with students graduating at the age of 15 or 16 . It was the sole system of education in Asia with only 10 years of combined primary-secondary education and one of only three in the world. A major reform was undertaken to lengthen the duration of schooling. Kindergarten was added in 2011 and then two further grades in 2016 and 2017. The current system has 6 years of elementary school, 4 years of junior secondary school and 2 years of senior secondary school. Students graduate at age 17 or 18 . The reform brought the length of schooling in line with K-12 systems common in other countries.

Understanding the prereform system is important because the data used for this study was obtained from households during 2015-2016. Under the old system, there was no vocational stream at secondary school. ${ }^{4}$ Students completed Grade 10 and then had three options: attend a TVET program at a college or related institution; enroll at university or other tertiary institution; or enter the job market. At that time and currently, the TVET system is managed by the Technical Education and Skills Development Authority, which accredits programs and organizes the system of skills certification of trainees. After training, students can sit an examination to obtain a National Certificate (NC), which is granted at levels I, II, III and IV, with the latter being the most advanced. Vocational training can also lead to a Certificate of Competency, for those who did not complete secondary school. There are also a variety of TVET opportunities that are not part of the NC system but lead to qualifications recognized by the industry and government. TVET is considered nontertiary education, whereas university and related higher-level education are classified as tertiary. It is also possible for an individual to pursue both TVET and tertiary education. We mention this case of combined education because of the interesting and often counter-intuitive results that it throws up later in the paper.

4 In the current system, a vocational track is offered in senior secondary school, leading to NCs I and II. 


\section{MODELS AND METHODOLOGIES}

The objective is to test the correlation between TVET and outcomes in the labor market. There are two outcomes of interest: the wage effect and employment effect (i.e., the likelihood of being employed). We begin by specifying a standard Mincerian wage model as follows:

$$
O_{i}=\beta_{0}+\beta_{1} E_{i}+\beta_{2} X_{i}+u_{i}
$$

where $O$ is either the wage or the employment effect, $E$ is educational attainment, and $X$ is work experience. Following standard notation, the $\beta \mathrm{s}$ are the variable coefficients, $\mu$ is the error term, and the subscript $i$ represents the individuals. Education can be a continuous variable for years of education or, as used here, a discrete variable for the type or level of education. We have six types: (i) secondary school or below, ${ }^{5}$ (ii) TVET, (iii) partial tertiary education without obtaining a diploma or degree, (iv) completed tertiary, (v) both TVET and partial tertiary, and (vi) both TVET and completed tertiary. Education is included in the model as dummy variables. Experience is an individual's current age minus the age at which the individual completed education. As such, our equation expands to:

$$
O=\beta_{0}+\beta_{1} V+\beta_{2} P+\beta_{3} T+\beta_{4} I+\beta_{5} C+\beta_{6} X+u
$$

where $V$ is TVET, $P$ is partial tertiary, $T$ is completed tertiary, $I$ is TVET and partial (incomplete) tertiary, and $C$ is TVET and completed tertiary. The $i$ subscripts are dropped for simplicity of presentation. Each of the education variables takes a value of 1 for that individual type of education and 0 otherwise. The base type is secondary school or below.

Such a specification may generate biased results due to omitted variables and result in inaccurate correlations between the education variables and the wage. Omitted variables would include other characteristics, besides education and experience, that affect the wage a worker receives. The other characteristics can include intelligence (or ability) and effort. A worker may be paid a higher wage because of her educational qualification but also because she is perceived by an employer as being more intelligent or as someone willing to work harder. If we exclude these variables, the effects are incorrectly captured by the (larger) size of the education coefficients. Conversely, if omitted factors are negatively correlated with education, the education variable would have a downward bias. ${ }^{6}$

Variables for intelligence and effort are not normally available. For ability, it is best to use test scores, such as secondary school examination results for both those who entered the workforce directly after school and those who continued to pursue TVET or tertiary education. Unfortunately, we do not have test results in the dataset. As a proxy, the educational attainment of the individual's mother is used. Fortunately, the survey did ask individuals whether they work hard to complete tasks and the responses are used as the variable to gauge effort. As such, the specification in equation (2) is expanded as follows:

$$
O=\beta_{0}+\beta_{1} V+\beta_{2} P+\beta_{3} T+\beta_{4} I+\beta_{4} C+\beta_{5} X+\beta_{6} A+\beta_{7} F+u
$$

5 Secondary school or below: denotes those whose highest educational attainment was (i) completed or did not complete secondary school, (ii) completed or did not complete primary (elementary) school, and (iii) did not attend school at all. In effect, it is any individual who did not attend TVET or tertiary education.

6 This might occur if TVET acts as an absorber of those who are not able to secure employment at a decent wage immediately after completing school. 
where $A$ represents ability and $F$ represents effort. Gender and control variables for sector and region are also included.

As noted, the data used for wage analysis is a subsample of the full sample and therefore is not random. Persons who pursued TVET or another type of education but were not working at the time of the survey did not have a wage to report. This problem of nonrandomness was identified by Heckman $(1976,1979)$. As such, we use a two-step Heckman correction procedure. The first step involves the estimation of the probability of employment (being employed) using a probit model. The result is used to compute the Inverse Mills Ratio which is then included as a regressor in the ordinary least squares (OLS) wage equation (second step) to control for possible bias due to nonrandomness.

In addition to dealing with nonrandom selection into employment, we have also sought to address nonrandom selection (participation) in TVET. As such, the second technique used for the wage effect is PSM (Rosenbaum and Rubin 1983). PSM is a common technique in education and employment studies to create comparable control and treatment groups (Graham and Kurlaender 2011). For this study, individuals with TVET (treatment group) are matched to individuals with similar characteristics except that they did not pursue TVET (control group). The procedure requires first that a propensity score is assigned to each individual by estimating the probability of obtaining TVET using the logit model. Then the scores of control and treatment groups are matched using a kernel matching method and the difference between groups is estimated. Variables for experience and gender are included as well as proxies for ability and effort, and control variables for industry. Considering the variations in the covariates between groups, we applied the procedure separately to the three education groups of the individuals: completed secondary, partial tertiary, and completed tertiary. Lastly, for each education group, we stratified the individuals into blocks. Then a test for balancing property was conducted for each block to determine whether the control and treatment groups were sufficiently similar to provide an accurate basis for comparison. The balancing property is satisfied if Rubin's B, which is the absolute standardized percentage difference of the means of the linear index of the propensity score in the treated and (matched) control group, is less than $25 \%$. It is also satisfied if Rubin's $\mathrm{R}$, which is the ratio of the treated to the (matched) control variances of the propensity score index, is between 0.5 and 2.0 (Rubin 2001).

For the employment effect, the analysis uses a multinomial logit model as follows:

$$
\operatorname{Prob}(O=j \mid Z)=\frac{\exp \left(z \beta_{j}\right)}{\sum_{j=1}^{3} \exp \left(Z \beta_{j}\right)}
$$

where $O$ is the dependent variable employment with three states $j$ which are: employed; unemployed (not working but seeking work); and not participating in the labor market (not working, not wanting to work). $Z$ are the same independent variables as in the wage effect analysis but including variables on age, having spouse, ability relative to father's education, and socioeconomic status. 


\section{CHARACTERISTICS OF THE SAMPLE}

The data is from the STEP Skills Measurement Household Survey 2015-2016 for the Philippines. It provides information on education, employment, wages, and other characteristics for 3,000 individuals between the ages of 15 and 64. The survey applied a four-stage sampling design. In the first stage, the primary sampling units which are composed of barangay segments in urban regions were selected through implicit stratification and systematic sampling. Within each selected primary sampling units, secondary sampling units, which are the dwellings, were systematically picked out. And then in each selected dwelling, a household was randomly chosen with equal probability. Finally, an individual aged 15-64 years old was randomly selected with equal probability from each selected household to complete the survey questionnaire (Pierre et al. 2014).

The data provide details on education that include not only the highest qualification obtained (certificate or degree) but also the years of study, which is important for those who pursued but did not complete a tertiary degree. For TVET, there is a breakdown by NC level. In addition, there is a category of Other TVET that does not lead to an NC but is recognized by the government and/or industry. A substantial portion of those who completed TVET are in this category. All those who undertook TVET in our dataset completed secondary school. The breakdown by NC level and the inclusion of a variable for effort are the chief advantages of the dataset over others, notable the labor force survey.

The full sample of 3,000 is used in the analysis of the employment effect. A subsample is used for the analysis of the wage effect as follows. Only those who are employed can provide data on wages and therefore those who were not employed are excluded. The self-employed were also excluded because it is difficult to determine a "wage" that is distinct from the income of the business. Also, the self-employed tend to introduce outliers, with very high earnings in some cases which are generated from entrepreneurial talent rather than skills acquired through education. As a result, the subsample for the wage effect includes a total of 980 individuals. This means that the subsample can no longer be considered truly random. As such, we apply a Heckman selection correction procedure in generating the estimates to control for a possible bias due to nonrandomness, as explained below. Summary statistics by education type are provided in Table 1. We find three distinct wage levels. At the lower end, the monthly average wage for those with primary education is about 5,000 Philippine peso (PHP). At the upper end, the average for nearly all categories of tertiary is above PHP13,000. In between these two levels are secondary school and TVET graduates with the average ranging from PHP11,000 to PHP12,000. Surprisingly, the average and median monthly wage for secondary school graduates is higher than for TVET. 
Table 1: Summary Statistics of Selected Profile by Highest Education Level

\begin{tabular}{|c|c|c|c|c|c|}
\hline Highest Level of Education & Persons & Percent & $\begin{array}{l}\text { Average } \\
\text { Age }\end{array}$ & $\begin{array}{c}\text { Average } \\
\text { Monthly } \\
\text { Income } \\
\text { (PHP) }\end{array}$ & $\begin{array}{c}\text { Median } \\
\text { Monthly } \\
\text { Income } \\
\text { (PHP) }\end{array}$ \\
\hline Did not complete elementary & 24 & 2.5 & 32.2 & 7,750 & 4,500 \\
\hline Elementary school graduate (Grade 6) & 240 & 24.5 & 35.3 & 5,049 & 4,450 \\
\hline $\begin{array}{l}\text { ALS Accreditation and Equivalency - Elementary Level } \\
\text { Passer }\end{array}$ & 71 & 7.2 & 36.8 & 5,085 & 5,000 \\
\hline Secondary school graduate (Grade 10) & 203 & 20.7 & 39.9 & 11,909 & 10,900 \\
\hline $\begin{array}{l}\text { ALS Accreditation and Equivalency - Secondary Level } \\
\text { Passer }\end{array}$ & 57 & 5.8 & 35.7 & 10,395 & 12,000 \\
\hline $\begin{array}{l}\text { Post-secondary TVET (National Certificates I, II, III, IV, } \\
\text { and Other post-secondary certificate) }\end{array}$ & 94 & 9.6 & 41.0 & 11,197 & 10,000 \\
\hline Associate in arts & 28 & 2.9 & 42.8 & 13,332 & 11,000 \\
\hline Bachelor's degree (4-year program) & 113 & 11.5 & 37.9 & 18,568 & 16,000 \\
\hline Bachelor's degree (5-year program) & 60 & 6.1 & 40.5 & 20,267 & 18,000 \\
\hline Bachelor professional degree $(6,7,8$ or 9 years $)$ & 52 & 5.3 & 41.3 & 15,177 & 12,750 \\
\hline Master's degree & 35 & 3.6 & 41.9 & 15,700 & 13,500 \\
\hline PhD degree & 3 & 0.3 & 39.0 & 12,500 & 11,500 \\
\hline Overall & 980 & 100.0 & 38.3 & 11,107 & 8,000 \\
\hline
\end{tabular}

ALS = Alternative Learning System, PHP = Philippine peso, TVET = technical and vocational education and training.

Sources: World Bank STEP Household Survey 2015-2016 Philippines; Authors' calculations.

Digging deeper, Table 2 provides a breakdown of wages and other characteristics by TVET level. Here we see considerable differences. The average wage for NC I, III, and IV are below PHP10,000. NCI is the lowest and accounts for the largest share-more than a third-of all TVET graduates. It is somewhat surprising that wages for NC III and IV are lower than for NC II. At the upper end, Other TVET certificate holders earn the highest average wage, which is like those who studied for a professional bachelor's or master's degree. This Other TVET category consists of training that is recognized by the government or industry but is not part of the NC system. The category provides the second-largest share of TVET-trained individuals in the sample. It is evident that the overall average TVET wage is pulled down by NCI and pushed up by Other TVET. 
Table 2: Characteristics of Workers Who Completed Secondary School and Post-Secondary Technical and Vocational Education and Training

\begin{tabular}{lrrrrrr}
\hline & $\begin{array}{c}\text { Secondary } \\
\text { School }\end{array}$ & NCI & NC II & NC III & NC IV & $\begin{array}{r}\text { Other } \\
\text { TVET }\end{array}$ \\
Profile & - & 38.3 & 11.7 & 7.5 & 11.7 & 30.9 \\
\hline Share of TVET sample (\%) & 11,909 & 8,220 & 11,909 & 9,950 & 9,409 & 15,602 \\
Monthly income - average (PHP) & 10,900 & 6,000 & 13,500 & 12,000 & 12,000 & 12,000 \\
$\begin{array}{l}\text { Monthly income - median (PHP) } \\
\text { Working in the same field as } \\
\quad \text { education (\%) }\end{array}$ & - & 16.7 & 0.0 & 0.0 & 45.5 & 3.5 \\
$\quad \begin{array}{l}\text { Average age (in years) } \\
\text { Socioeconomic status at age 15 (\%) }\end{array}$ & 39.9 & 41.3 & 35.4 & 40.1 & 43.5 & 42.2 \\
$\quad$ Low & 20.2 & 19.4 & 9.1 & 42.9 & 9.1 & 10.3 \\
$\quad$ Middle & 52.7 & 61.1 & 63.6 & 42.9 & 54.6 & 58.6 \\
$\quad$ High & 27.1 & 19.4 & 27.3 & 14.3 & 36.4 & 31.0 \\
$\quad$ School type (\%) & & & & & & \\
$\quad$ Public & - & 66.7 & 81.8 & 57.1 & 45.5 & 58.6 \\
$\quad$ Private & - & 33.3 & 18.2 & 28.6 & 54.6 & 37.9 \\
\hline
\end{tabular}

NC = national certificate, $\mathrm{PHP}=$ Philippine peso, TVET = technical and vocational education and training.

Notes: Percentages may not add up to 100 due to rounding. Where school type sums to less than $100 \%$, it is due to omitted types, namely home schooling for NC III (14.3\%) and mixed public-private for Other TVET (3.5\%).

Sources: World Bank STEP Household Survey 2015-2016 Philippines; Authors' calculations.

There is no significant relationship between the field of study and an individual's current area of work for the different levels of TVET.7 There is a 45\% match for NC IV and a 17\% match for NC I, which are the TVET levels with the lowest average wages. For the three other levels, the match is at or close to zero. These results are counterintuitive, as we might think that those who find work in their field of study would be rewarded with good wages for their sector-specific skills gained during training. In terms of school type, there is a tendency for more of the individuals in the higher wage TVET levels (NC II and Other) to have been trained at public as opposed to private training institutes. The table also includes an individual's retrospective self-assessment of socioeconomic status at age 15 . The levels NC II, IV, and Other tend to include few individuals who identified as low status and a large share who identified as high status.

Regarding the employment effect, TVET graduates have a higher employment rate than all other levels of education (Table 3). The difference appears substantial as $94 \%$ of those with vocational training were employed, compared to about $90 \%$ for the other categories. Men have a higher employment rate than women. The figures on age suggest a lower employment rate for the young and for those over age 30, with as much as a 3 percentage point difference to those aged 20-30 years.

The survey data provided an individual's area of study and her or his sector of current work. We tested for relationships using Pearson's chi-square and found no significant associations. The results are not shown. 
Table 3: Share of Persons Employed in the Sample

\begin{tabular}{lc}
\hline & $\begin{array}{c}\text { Employed } \\
\text { (\%) }\end{array}$ \\
\hline Education & \\
$\quad$ Partial secondary & 89.0 \\
Completed secondary & 89.1 \\
TVET & 94.0 \\
Partial tertiary & 90.7 \\
Completed tertiary & 89.7 \\
Gender & \\
Male & 91.1 \\
Female & 87.0 \\
Age group (in years) & \\
15-25 & 90.2 \\
20-25 & 92.8 \\
20-30 & 91.8 \\
30-64 & 89.1 \\
Married & \\
No & 89.5 \\
Yes & 89.2 \\
\hline
\end{tabular}

TVET = technical and vocational education and training.

Note: Persons employed as percentage of persons employed and unemployed (i.e., not working but looking for work). Total observations are 1,894.

Sources: World Bank STEP Household Survey 2015-2016 Philippines; Authors' calculations.

\section{RESULTS}

The results for the wage effect are provided in Table 4, based on OLS estimation with Heckman correction to account for the nonrandomness of selection into employment. There is a positive correlation between wages and TVET, relative to the base case, which is secondary school or below. The result is present across the four specifications and is significant in three models. This confirms our basic notion that TVET provides a wage advantage over those who only attended secondary school or below. Partial and completed tertiary education are also significant and positive, with larger coefficients than TVET, as might be expected. 
Table 4: Determinants of Wage

\begin{tabular}{|c|c|c|c|c|}
\hline Variables & Model 1 & Model 2 & Model 3 & Model 4 \\
\hline \multirow[t]{2}{*}{ TVET } & 0.093 & $0.501^{* * *}$ & $0.459^{* * *}$ & $0.483^{* * *}$ \\
\hline & $(0.140)$ & $(0.137)$ & $(0.144)$ & $(0.144)$ \\
\hline \multirow[t]{2}{*}{ Partial tertiary } & $0.420^{* * *}$ & $0.724^{* * *}$ & $0.669^{* * *}$ & $0.694^{* * *}$ \\
\hline & $(0.102)$ & $(0.095)$ & $(0.122)$ & $(0.124)$ \\
\hline \multirow[t]{2}{*}{ Completed tertiary } & $1.088^{* * *}$ & $1.175^{* * *}$ & $1.143^{* * *}$ & $1.201^{* * *}$ \\
\hline & $(0.064)$ & $(0.059)$ & $(0.076)$ & $(0.082)$ \\
\hline \multirow[t]{2}{*}{ TVET_Partial tertiary } & & $-1.107^{* * *}$ & $-0.910^{* * *}$ & $-0.935^{* * *}$ \\
\hline & & $(0.230)$ & (0.239) & $(0.237)$ \\
\hline \multirow[t]{2}{*}{ TVET_Completed tertiary } & & $-1.111^{* *}$ & $-1.036^{* *}$ & $-1.075^{* * *}$ \\
\hline & & $(0.471)$ & $(0.416)$ & $(0.407)$ \\
\hline \multirow[t]{2}{*}{ Experience } & $0.026^{* * *}$ & $0.024^{* * *}$ & $0.025^{* * *}$ & $0.023^{* * *}$ \\
\hline & $(0.004)$ & $(0.004)$ & $(0.004)$ & $(0.004)$ \\
\hline \multirow[t]{2}{*}{ Experience squared } & $-0.0002^{* * *}$ & $-0.0002^{* * *}$ & $-0.0002^{* * *}$ & $-0.0002^{* * *}$ \\
\hline & $(0.000)$ & $(0.000)$ & $(0.000)$ & $(0.000)$ \\
\hline \multirow[t]{2}{*}{ Gender (Female) } & & & 0.017 & -0.022 \\
\hline & & & $(0.159)$ & $(0.159)$ \\
\hline \multirow[t]{2}{*}{ Educated mother } & & & -0.006 & -0.001 \\
\hline & & & $(0.060)$ & $(0.059)$ \\
\hline \multirow[t]{2}{*}{ Work hard to do things well and on time } & & & 0.113 & 0.159 \\
\hline & & & $(0.145)$ & $(0.146)$ \\
\hline \multirow[t]{2}{*}{ IMR } & -0.132 & -0.099 & -0.119 & -0.001 \\
\hline & $(0.160)$ & $(0.155)$ & $(0.424)$ & $(0.420)$ \\
\hline \multirow[t]{2}{*}{ Constant } & $8.205^{* * *}$ & $8.150^{* * *}$ & $8.075^{* * *}$ & $8.129^{* * *}$ \\
\hline & $(0.121)$ & $(0.117)$ & $(0.222)$ & $(0.235)$ \\
\hline Sector dummy & No & No & No & Yes \\
\hline Region dummy & No & No & Yes & Yes \\
\hline Observations & 980 & 980 & 980 & 980 \\
\hline R-squared & 0.301 & 0.334 & 0.364 & 0.374 \\
\hline $\mathrm{F}$ & $65.98^{* * *}$ & $58.65^{* * *}$ & $23.95^{* * *}$ & $22.50^{* * *}$ \\
\hline
\end{tabular}

IMR = Inverse Mills Ratio, TVET = technical and vocational education and training.

Notes: Ordinary least squares estimation, including a Heckman correction for nonrandomness due to the truncated sample. Dependent variable: log monthly wage. ${ }^{* *} p<0.01,{ }^{* *} p<0.05,{ }^{*} p<0.1$. Robust standard errors in parentheses. International Standard Classification of Education (ISCED) 3 and above for educated mother.

Sources: World Bank STEP Household Survey 2015-2016 Philippines; Authors' calculations.

The variable for effort ("work hard to do things well and on time") is positive but not significant. Mother's education, a proxy for the intelligence or ability of their son or daughter, is also positive but not significant and the coefficient is small. Nonetheless, the inclusion of these two variables in Models 3 and 4 reduces substantially the size of the coefficients on the education variables, including TVET, compared to Model $2 .{ }^{8}$ The smaller coefficients are to be expected and demonstrate that omitting these variables would inflate the effect of education on wages. Model 4 includes a dummy variable for sector, which improves the fit and increases the absolute value of the coefficients on all the education-related variables relative to Model 3.

8 Model 3 also includes a regional dummy variable which could also affect the results, but our investigation (not shown) indicates that the effect is very minor. 
The variables for individuals who pursued both TVET and tertiary education are also significant, but with a negative sign. In effect, those who combined these two types of post-secondary education earned lower wages than those who attended secondary school or below. At first glance, this result is unexpected and puzzling. However, a statistical breakdown of these two-level individuals is informative. Table 5 indicates that nearly all tertiary level students who also did TVET completed only NC I, which, as shown in Table 2, has the lowest average wage among the various levels of TVET. Furthermore, most of these dual-level individuals completed only 2 years of tertiary education. Thus, these individuals can be considered low attainers in both TVET and tertiary education. The idea that when TVET is added to tertiary education, it penalizes an individual in terms of wages, as suggested by Olfindo (2018), may be a bit strong when considering the educational paths of these individuals.

\section{Table 5: Number of Post-Secondary Technical and Vocational Education and Training by Highest Year Completed}

\begin{tabular}{|c|c|c|c|c|c|c|}
\hline \multirow[b]{2}{*}{ Highest Year Completed } & \multicolumn{5}{|c|}{ Post-Secondary TVET } & \multirow[b]{2}{*}{ Total } \\
\hline & $\mathrm{NCl}$ & NC II & NC III & NCIV & Other TVET & \\
\hline Post-secondary TVET - 1st year & 4 & 3 & 2 & - & 7 & 16 \\
\hline Post-secondary TVET - 2nd year & - & 1 & 1 & 2 & 8 & 12 \\
\hline Post-secondary TVET - 3rd year & 8 & 7 & 4 & 9 & 9 & 37 \\
\hline Associate in arts program - 1st year & 2 & - & - & - & 2 & 4 \\
\hline Associate in arts program - 2nd year & 6 & - & - & - & 2 & 8 \\
\hline \multicolumn{7}{|l|}{ Associate in arts program - 3rd year } \\
\hline Bachelor program - 1st year & 7 & - & - & - & - & 7 \\
\hline Bachelor program - 2nd year & 4 & - & - & - & - & 4 \\
\hline Bachelor program - 3rd year & 1 & - & - & - & 1 & 2 \\
\hline Bachelor program - 4th year & 4 & - & - & - & - & 4 \\
\hline Overall & 36 & 11 & 7 & 11 & 29 & 94 \\
\hline
\end{tabular}

$\mathrm{NC}=$ national certificate, $\mathrm{TVET}=$ technical and vocational education and training.

Sources: World Bank STEP Household Survey 2015-2016 Philippines; Authors' calculations.

The second method used is PSM, which matches individuals in the control and treatment groups. First, the logit propensity score is estimated for TVET (which takes the value 1) and non-TVET (which takes the value 0) for each of the three types of educational attainment as presented in Table 6. ${ }^{9}$ These results are then used in the calculation for PSM in Table 7. The first column in the latter table shows a comparison between secondary school graduates who pursued TVET and those who did not. The average treatment effect on the treated is positive and significant, indicating higher wages for TVET individuals matched with others who graduated secondary school but did not pursue further education. The second column matches TVET and non-TVET graduates for all those individuals who obtained some tertiary education. The result is significant and negative and is likely explained by the reasons given above that these dual-education individuals have the lowest attainment of both TVET and tertiary education. The third column shows a negative average treatment effect on the treated for TVET graduates relative to non-TVET graduates, among all those

9 The number of observations is low in the "partial tertiary" regression of Table 6. Nonetheless, the likelihood ratio chisquare test is significant for all three regressions. 
who completed tertiary education, but it is not significant. The tests of balancing property are satisfied for Rubin's B and R in all three cases, suggesting that good matching was possible.

\section{Table 6: Logistic Regression for the Propensity Score (Technical and Vocational Education and Training versus Other Levels of Education)}

\begin{tabular}{lccc}
\hline Variables & Completed Secondary & Partial Tertiary & Completed Tertiary \\
\hline Experience & $0.057^{*}$ & 0.028 & -0.090 \\
& $(0.033)$ & $(0.052)$ & $(0.061)$ \\
Experience squared & $-0.001^{* * *}$ & -0.0001 & 0.001 \\
& $(0.000)$ & $(0.001)$ & $(0.001)$ \\
Gender (Female) & 0.135 & $1.572^{* * *}$ & -0.764 \\
& $(0.315)$ & $(0.548)$ & $(0.641)$ \\
Educated mother & $0.740^{* *}$ & -0.943 & 0.443 \\
& $(0.346)$ & $(0.657)$ & $(0.653)$ \\
Work hard to do things well and on time & $1.162^{* * *}$ & $1.382^{* *}$ & 1.877 \\
& $(0.342)$ & $(0.673)$ & $(1.168)$ \\
Constant & $-2.616^{* * *}$ & -1.656 & -0.084 \\
& $(0.865)$ & $(1.136)$ & $(1.689)$ \\
Sector dummy & Yes & Yes & Yes \\
\hline Observations & 292 & 84 & 269 \\
Pseudo R-squared & 0.182 & 0.161 & 0.149 \\
LR Chi-square & $57.59^{* * *}$ & $17.81^{* *}$ & $15.52^{* *}$ \\
\hline
\end{tabular}

$\mathrm{LR}=$ likelihood ratio.

Notes: ${ }^{* *} p<0.01,{ }^{* *} p<0.05,{ }^{*} p<0.1$. Standard errors in parentheses. Dependent variable takes the value 1 in all three cases for individuals who took TVET only and 0 for those who completed (i) only secondary school, (ii) combined TVET with partial tertiary, or (iii) combined TVET with completed tertiary education. International Standard Classification of Education (ISCED) 3 and above for educated mother.

Sources: World Bank STEP Household Survey 2015-2016 Philippines; Authors' calculations.

Table 7: Differences in Log Monthly Wage between Technical and Vocational Education and Training and Other Levels of Education Using Propensity Score Matching

\begin{tabular}{lcrr}
\hline Variables & Completed Secondary & Partial Tertiary & Completed Tertiary \\
\hline ATT & $0.265^{* *}$ & $-0.580^{* * *}$ & -0.604 \\
Standard error & 0.118 & 0.208 & 0.405 \\
t-value & 2.200 & -2.954 & -1.544 \\
Observations & 225 & 80 & 141 \\
Treatment & 67 & 27 & 12 \\
Control & 158 & 53 & 129 \\
Test of balancing property & Satisfied & Satisfied & Satisfied \\
Rubin's B & 10.7 & 16.5 & 20.6 \\
Rubin's R & 0.7 & 0.9 & 0.8 \\
\hline
\end{tabular}

ATT = average treatment effect on the treated.

Notes: ATT was estimated using the kernel matching method. $t$-values are significant at ${ }^{* * *} p<0.01,{ }^{* *} p<0.05,{ }^{*} p<0.1$. Standard errors are bootstrapped using 200 repetitions. Number of observations in the treatment and control groups refers to actual kernel matches. The table shows differences between those who took TVET only and those who (i) completed only secondary school, (ii) combined TVET with partial tertiary, or (iii) combined TVET with completed tertiary. Balancing property is satisfied if Rubin's $B<25 \%$ and $0.5<R<2.0$.

Sources: World Bank STEP Household Survey 2015-2016 Philippines; Authors' calculations. 
Lastly, we estimate the employment effect for various levels of education, based on the model presented at the end of section IV. Table 8 provides the results for two estimations, with the second one including additional control variables. The base case for education is secondary school or below. Unlike the analysis on wages, these results use the full sample of 3,000 individuals. Each person is classified into one of three categories: employed, unemployed, and not seeking work, following standard labor market classification. The unemployed are not working but wish to work and are part of the labor market. Those not seeking work (and not working) are not part of the labor market. This third category includes full-time students, the discouraged who have given up looking for work, and adults taking care of the home (including looking after children and elderly parents).

The results show a much stronger employment effect for TVET graduates than for all other levels of education. Those who pursued TVET are more likely to be employed and less likely to be out of the labor market than those who only attended secondary school or below. The results are statistically significant. TVET graduates are also less likely to be unemployed, although it is not significant. The employment effect for those who pursued tertiary education are quite the opposite. Those who studied at the tertiary level and either graduated or had not finished were less likely to be employed and more likely to be out of the labor market than those who attended secondary school or below. Many of those who had not finished tertiary were not in the workforce because they were still in education. Only a minority of these results across the four tertiary-related education variables are significant.

Among the noneducation variables, we find that young persons between the ages of 20 and 30 and married women are less likely to be employed and less likely to be in the labor force. These results are highly statistically significant and probably not surprising given the difficulty for women and youth to find jobs, and the greater tendency to be either caring for children or in education, respectively. It is recognized that the noneducation variables offer only a limited control on the nonrandom selection of individuals into TVET.

Table 8: Employment Probability, Marginal Effects

\begin{tabular}{|c|c|c|c|c|c|c|}
\hline \multirow[b]{2}{*}{ Variables } & \multicolumn{3}{|c|}{ Model 1} & \multicolumn{3}{|c|}{ Model 2} \\
\hline & Employed & Unemployed & $\begin{array}{c}\text { Not } \\
\text { Working, } \\
\text { Not Seeking }\end{array}$ & Employed & Unemployed & $\begin{array}{c}\text { Not } \\
\text { Working, } \\
\text { Not Seeking }\end{array}$ \\
\hline \multirow[t]{2}{*}{ TVET } & $0.144^{* * *}$ & -0.039 & $-0.106^{* *}$ & $0.145^{* * *}$ & -0.038 & $-0.107^{* *}$ \\
\hline & $(0.041)$ & $(0.028)$ & $(0.046)$ & $(0.041)$ & $(0.028)$ & $(0.045)$ \\
\hline \multirow[t]{2}{*}{ Partial tertiary } & -0.061 & -0.018 & $0.079^{* *}$ & -0.054 & -0.014 & $0.068^{*}$ \\
\hline & $(0.037)$ & $(0.024)$ & $(0.035)$ & $(0.036)$ & $(0.023)$ & $(0.035)$ \\
\hline \multirow[t]{2}{*}{ Completed tertiary } & $-0.037^{*}$ & -0.003 & $0.040^{*}$ & -0.028 & -0.001 & 0.029 \\
\hline & $(0.022)$ & $(0.012)$ & $(0.022)$ & $(0.022)$ & $(0.012)$ & $(0.022)$ \\
\hline \multirow[t]{2}{*}{ TVET_Partial tertiary } & 0.001 & 0.057 & -0.059 & 0.004 & 0.058 & -0.062 \\
\hline & $(0.083)$ & $(0.050)$ & $(0.085)$ & $(0.079)$ & $(0.052)$ & $(0.082)$ \\
\hline \multirow[t]{2}{*}{ TVET_Completed tertiary } & 0.024 & 0.034 & -0.058 & 0.000 & 0.044 & -0.044 \\
\hline & (0.097) & $(0.065)$ & $(0.120)$ & $(0.090)$ & $(0.065)$ & (0.111) \\
\hline \multirow[t]{2}{*}{ Years of experience } & $-0.004^{* * *}$ & -0.001 & $0.005^{* * *}$ & $-0.006^{* * *}$ & $-0.001^{*}$ & $0.007^{* * *}$ \\
\hline & (0.001) & $(0.001)$ & $(0.001)$ & (0.001) & $(0.001)$ & (0.001) \\
\hline \multirow[t]{2}{*}{ Years of experience squared } & 0.000 & 0.000 & -0.000 & $0.00002^{*}$ & 0.000 & $-0.00003^{* * *}$ \\
\hline & $(0.000)$ & $(0.000)$ & $(0.000)$ & $(0.000)$ & $(0.000)$ & $(0.000)$ \\
\hline \multirow[t]{2}{*}{ Age (20-30 years old) } & & & & $-0.068^{* * *}$ & $-0.038^{* * *}$ & $0.106^{* * *}$ \\
\hline & & & & $(0.024)$ & (0.015) & $(0.023)$ \\
\hline
\end{tabular}


Table 8 continued

\begin{tabular}{|c|c|c|c|c|c|c|}
\hline \multirow[b]{2}{*}{ Variables } & \multicolumn{3}{|c|}{ Model 1} & \multicolumn{3}{|c|}{ Model 2} \\
\hline & Employed & Unemployed & $\begin{array}{c}\text { Not } \\
\text { Working, } \\
\text { Not Seeking }\end{array}$ & Employed & Unemployed & $\begin{array}{c}\text { Not } \\
\text { Working, } \\
\text { Not Seeking }\end{array}$ \\
\hline \multirow[t]{2}{*}{ Gender (Female) } & $-0.201^{* * *}$ & 0.003 & $0.197^{* * *}$ & $-0.120^{* * *}$ & -0.023 & $0.143^{* * *}$ \\
\hline & $(0.017)$ & $(0.009)$ & $(0.017)$ & $(0.028)$ & $(0.016)$ & $(0.027)$ \\
\hline \multirow[t]{2}{*}{ Married } & $0.041^{* *}$ & 0.010 & $-0.051^{* * *}$ & $0.108^{* * *}$ & -0.015 & $-0.093^{* * *}$ \\
\hline & $(0.019)$ & $(0.010)$ & $(0.019)$ & $(0.027)$ & $(0.015)$ & $(0.027)$ \\
\hline \multirow{2}{*}{ Gender (Female)_Married } & & & & $-0.141^{* * *}$ & $0.048^{* *}$ & $0.093^{* *}$ \\
\hline & & & & $(0.037)$ & $(0.021)$ & $(0.036)$ \\
\hline \multirow[t]{2}{*}{ Educated mother } & 0.015 & 0.011 & -0.026 & 0.029 & 0.017 & $-0.047^{*}$ \\
\hline & $(0.023)$ & $(0.011)$ & $(0.022)$ & $(0.024)$ & $(0.012)$ & $(0.024)$ \\
\hline \multirow[t]{2}{*}{ Educated father } & & & & -0.018 & -0.014 & 0.032 \\
\hline & & & & $(0.022)$ & $(0.011)$ & $(0.022)$ \\
\hline Socioeconomic status at age 15 & No & No & No & Yes & Yes & Yes \\
\hline Region & Yes & Yes & Yes & Yes & Yes & Yes \\
\hline Observations & 3,000 & 3,000 & 3,000 & 3,000 & 3,000 & 3,000 \\
\hline
\end{tabular}

TVET = technical and vocational education and training.

Notes: The models are estimated from Multinomial Logit estimation. ${ }^{* *} p<0.01,{ }^{* *} p<0.05,{ }^{*} p<0.1$. Heteroscedasticity-corrected standard errors in parentheses. International Standard Classification of Education (ISCED) 3 and above for educated mother or father.

Sources: World Bank STEP Household Survey 2015-2016 Philippines; Authors' calculations.

\section{CONCLUSION}

The developing world may be affected by a learning crisis in which the low quality of educational provision results in weak learning outcomes. At the primary and secondary levels, learning can be measured by standardized tests. Similar tests for post-secondary education are less practical, given subject diversity. Instead, the impact of learning can be measured by labor market outcomes; that is, the willingness of employers to hire graduates (employment effect) and to pay decent wages (wage effect). When employers are willing to pay a premium for educated and trained graduates, over less educated ones, this can be interpreted as an indication that learning was acquired..$^{10}$ At the individual level, good labor market outcomes are necessary to justify the investment in education, in terms of time (opportunity cost) and money spent on tuition and other expenses.

The study has focused on the labor market outcomes of individuals who pursued TVET in the Philippines. TVET graduates were compared to those who were only taught at secondary school or below and comparisons were also made with those who pursued tertiary education, such as university. The analysis was based on a sample of 3,000 adults in 2015-2016.

10 There may also be a signaling effect in which students with higher ability find it less costly (difficult) to obtain education and therefore they continue their education longer. Employers thus use years of education as a signal for ability and pay a premium for it (Spence 1973). 
TVET graduates are more likely to be employed and receive a higher wage than those who were only taught at secondary school or below. The results are statistically significant for both the Heckman-corrected OLS model and the PSM technique. TVET graduates are also more likely to be employed than those who pursed tertiary education. These results provide the answer to the question posed in the title of the paper: TVET is not irrelevant in the labor market job but can be effective in securing employment and obtaining a better wage than for those who do not pursue post-secondary education.

We also considered individuals who combined TVET and tertiary education. Here we found that those who completed TVET and, in addition, either completed or pursued some tertiary education earned lower wages than those who only completed secondary school or below. The results were the same for Heckman-corrected OLS and PSM. However, for those who completed tertiary education, the estimate was not significant for PSM.

The puzzling result-that those who combine TVET and tertiary education receive low wages -is probably partly explained by the level of attainment. These individuals tend to complete only NCI and only 1 or 2 years of tertiary education. These are the least remunerative levels of postsecondary education. The chief policy implication from this study flows from that finding. Short stints of education, especially combining the TVET and tertiary levels, may not be rewarded in the labor market. It may be best to encourage students to progress beyond NC I to NC II, rather than attempt a jump to university. 


\section{REFERENCES}

Asian Development Bank (ADB). 2015. A Smarter Future: Skills, Education and Growth in Asia. Manila. https://www.adb.org/sites/default/files/publication/175162/ki2015-special-chapter.pdf.

Attanasio, Orazio, Arlen Guarin, Carlos Medina, and Costas Meghir. 2015. "Long-Term Impacts of Vouchers for Vocational Training: Experimental Evidence for Columbia." NBER Working Paper No. 21390.

Attanasio, Orazio, Adriana Kugler, and Costas Meghir. 2011. "Subsidizing Vocational Training for Disadvantaged Youth in Columbia: Evidence from a Randomized Trial." American Economic Journal: Applied Economics 3 (3): 188-220.

Becker, Gary. 1964. Human Capital, 2nd edition. New York: Columbia University Press.

Bettinger, Eric, Michael Kremer, and Juan Saavedra. 2010. "Are Education Vouchers Only Redistributive? Economic Journal 120 (546): 204-28.

Card, David, Pablo Ibarraran, Ferdinando Regalia, David Rosas-Shady, and Yuri Soares. 2011. "The Labor Market Impacts of Youth Training in the Dominican Republic." Journal of Labor Economics 29 (2): 267-300.

Choi, Seonkyung. 2016. "Effects of Vocational Education on Wage: Case of the Philippines." Journal of Economics and Sustainable Development 7 (10): 27-51.

Field, Erica, Leigh Linden, Ofer Malamud, Daniel Rubenson, and Shing-Yi Wang. 2019. "Does Vocational Education Work? Evidence from a Randomized Experiment in Mongolia." NBER Working Paper No. 26092.

Graham, Suzanne, and Michal Kurlaender. 2011. "Using Propensity Scores in Education Research: General Principles and Practical Applications." Journal of Educational Research 104: 340-53.

Heckman, James. 1976. "The Common Structure of Statistical Models of Truncation, Sample Selection and Limited Dependent Variables and a Simple Estimator for Such Models." Annals of Economic and Social Measurement 5 (4): 475-92.

1979. "Sample Selection Bias as a Specification Error.” Econometrica 47 (1): 153-61.

Hicks, Joan, Michael Kremer, Isaac Mbiti, and Edward Miguel. 2016. "Evaluating the Impact of Vocational Education Vouchers on Out-of-School Youth in Kenya." Impact Evaluation Report 37. International Initiative for Impact Evaluation.

Hirshleifer, Sarojini, David McKenzie, Rita Almeida, and Cristobal Ridao-Cano. 2016. "The Impact of Vocational Training for the Unemployed: Experimental Evidence from Turkey." The Economic Journal 126 (597): 2115-46. 
Kluve, Jochen, Susana Puerto, David Robalino, Jose Manuel Romero, Friederike Rother, Jonathan Stoterau, Felix Weidenkaff, and Marc Witte. 2016. "Do Youth Employment Programs Improve Labor Market Outcomes? A Systematic Review." IZA Institute of Labor Economies Discussion Paper No. 10263.

Lee, Jong-Wha, Jong-Suk Han, and Eunbi Song. 2019. "The Effects and Challenges of Vocational Training in Korea." International Journal of Training Research 17 (S1): 96-111.

Mackenzie, David. 2017. "How Effective are Active Labor Market Policies in Developing Countries? A Critical Review of Recent Evidence.” World Bank Policy Research Working Paper No. 8011.

Malamud, Ofer, and Cristian Pop-Eleches. 2010. "General Education versus Vocational Training: Evidence from an Economy in Transition." Review of Economics and Statistics 92 (1): 43-60.

Mincer, Jacob. 1974. Schooling, Experience and Earnings. Cambridge, MA: National Bureau of Economic Research.

Olfindo, Rosechin. 2018. "Rethinking Vocational Education in the Philippines: Does It Really Lead to Higher Wages?” Journal of Southeast Asian Economies 35 (1): 79-100.

Pierre, Gaelle, Maria Sanchez Puerta, Alexandria Valerio, and Tania Rajadel. 2014. "STEP Skills Measurement Surveys: Innovative Tools for Assessing Skills.” World Bank. Social Protection and Labor Discussion Paper 1421. http://documents1.worldbank.org/curated/en/516741468178736065/pdf/ 897290NWPOP132085290B00PUBLIC001421.pdf.

Rosenbaum, Paul, and Donald Rubin. 1983. "The Central Role of the Propensity Score in Observational Studies for Causal Effects. Biometrika 70 (1): 41-55.

Rubin, Donald. 2001. "Using Propensity Scores to Help Design Observational Studies: Application to the Tobacco Litigation." Health Services and Outcomes Research Methodology 2: 169-88.

Schultz, Theodore. 1961. “Investment in Human Capital.” American Economic Review 51 (1): 1-17.

Spence, Michael. 1973. “Job Market Signaling.” Quarterly Journal of Economics 87 (3): 355-74. 


\section{The Impact of Vocational Training on Labor Market Outcomes in the Philippines}

The paper analyzes the labor market outcomes of technical and vocational education and training (TVET) in the Philippines. TVET graduates earn significantly higher wages than those who entered the job market with a secondary school education or below. However, individuals who both trained in TVET and pursued tertiary education earn less than those with secondary school or below. This counterintuitive result is explained by the tendency for such dual-level individuals to complete the lowest level of TVET. Graduates of TVET are also more likely to be employed than those who studied at other levels.

\section{About the Asian Development Bank}

ADB is committed to achieving a prosperous, inclusive, resilient, and sustainable Asia and the Pacific, while sustaining its efforts to eradicate extreme poverty. Established in 1966, it is owned by 68 members -49 from the region. Its main instruments for helping its developing member countries are policy dialogue, loans, equity investments, guarantees, grants, and technical assistance. 